\title{
Influence of Ladle Addition Practice on the Castability of Typical Low Carbon Low Silicon Steel
}

\author{
Anil Kumar ${ }^{1, ~ *}$, Shiv Kumar Choudhary ${ }^{1}$, Saroj Kumar Singh ${ }^{2}$ \\ ${ }^{1}$ Research and Development, Tata Steel Limited, Jamshedpur, India \\ ${ }^{2}$ Steelmaking and Casting Division, Tata Steel Limited, Jamshedpur, India
}

Email address:

dr.anilkumar@tatasteel.com (A. Kumar)

${ }^{*}$ Corresponding author

\section{To cite this article:}

Anil Kumar, Shiv Kumar Choudhary, Saroj Kumar Singh. Influence of Ladle Addition Practice on the Castability of Typical Low Carbon Low Silicon Steel. International Journal of Mineral Processing and Extractive Metallurgy. Vol. 3, No. 1, 2018, pp. 1-14. doi: $10.11648 /$ j.ijmpem.20180301.11

Received: April 25, 2018; Accepted: May 14, 2018; Published: June 12, 2018

\begin{abstract}
Continuous casting of low carbon low silicon steel processed though Basic Oxygen Furnace (BOF) followed by Online Purging station (OLP) and Ladle Furnace (LF) inherently suffers from the problem of clogging of submerged entry nozzles (SEN) during casting due to gradual alumina deposition at the inner surface of the refractory wall. This restricts the incoming flow of liquid steel from tundish to mould through SEN and thus limits the productivity of the caster. On the other hand, excess alumina deposition and their periodic dislodgement from the nozzle refractory surface gives rise to undue stopper rod movement and melt level fluctuations in the mould. All these abnormalities lead to decreased production of good quality slabs. In the present work, influence of ladle addition practice on the castability of typical low carbon low silicon steel has been investigated for a conventional thick slab caster. For identification of inclusions characteristics at different stages of processing, liquid steel samples were collected using the lollipop and a specially designed large sampler during casting. Also, the clog deposits in the used SEN and the natures of inclusions in the clog deposits as well as in the liquid steel were identified by SEM-EDS analysis. Subsequently, to measure the process the different plant trials were carried out for several casting sequences using different deoxidation practices. The upstream processing parameter and corresponding casting data with nozzle clogging index (NCI) for a complete casting sequence were examined for evaluating their casting performances. Addition practice of deoxidant and lime during the ladle treatment has been found to have an important effect of the liquid steel casting. It has been clearly demonstrated the faulty addition practice can lead to severe nozzle clogging during casting. Though a series of plant trials the best addition practice has been determined and implemented in the regular production in the plant for ensuring the smooth production of the given grade of steel. For the quantification of steel cleanliness, total oxygen content ( $\mathrm{T}[\mathrm{O}]$ ) of liquid steel, was measured from the samples collected after each ladle treatment stage. $\mathrm{T}[\mathrm{O}]$ of liquid steel was found in the range of 60-120 ppm at OLP and 30-55 ppm at tundish of low carbon low silicon grade of steel.
\end{abstract}

Keywords: Al Killed Steel, Ladle Treatment, Slab Casting, SEM-EDS, Alumina, Inclusions, Nozzle Clogging, Clogging Index

\section{Introduction}

Aluminium killed steel inherently suffers from the problem of nozzle clogging during continuous casting [1,2]. There is gradual deposition of residual fine alumina and other solid non-metallic inclusions (NMI) at the wall of refractory submerged entry nozzles (SEN), restricting the passage flow of liquid steel through them during casting operation.
Therefore, nozzle clogging has been considered as one of the important process upsets in the smooth production of Alkilled steel. Alumina in liquid steel originates from residual unfloated deoxidation products of ladle treatment and those generated subsequently from reoxidation reactions of liquid steel during subsequent transfer operations [3, 4]. Besides these physical entrapments of solid exogenous particles and those generated from unintentional side reactions between liquid steel and refractory also give rise to additional solid 
inclusions $[5,6]$. Such steels are commonly produce through three process routes viz., (a) direct route where liquid steel is sent directly for the casting just after primary deoxidation and argon rinsing (ARS) treatment in the ladle during tapping from the vessel, (b) in the $L F$ route where liquid steel is further treated in the ladle furnace after ARS before casting, and (c) $R H$ route where liquid steel is first homogenised and partially deoxidised after the vessel tapping and ARS then subjected to treatment in the RH degasser before casting. Amongst these routes, casting of LF treated steel has been found to be more problematic in comparison to other routes. During liquid steel casting, the severity of nozzle clogging is commonly judged by monitoring the movement of tundish stopper rod, mould level fluctuations (MLF) and frequency of argon flushing. Undue MLF arising from the sudden dislodgement of large alumina chunks from the nozzle deposit hampers smooth casting operations, and leads to downgrading of costly cast slabs besides limiting the caster productivity.

Direct quantification of nozzle clogging is difficult as nothing is visible during casting. Indirectly, nozzle clogging index (NCI) has been widely adopted for judging the level of liquid steel cleanliness and its casting performance [7]. For a more realistic assessment a dynamic clogging index has been developed to keep track of the nozzle clogging during casting $[8,9]$. Dynamic clogging index is based on the actual casting variables such as: stopper rod position, tundish weight, casting speed, etc. In this model, NCI data is continuously recorded at every 5 second during casting and thus about 700-900 data are generated per heat depending upon the casting duration. The slope of the NCI versus time data is continuously calculated during casting. Subsequently, slopes of the NCI plots statistically correlated with the upstream steelmaking parameters for establishing their role in alumina deposition in SEN during casting. In view of this present work has been undertaken for establishing the prime causes of clogging in low carbon Al killed grades and find out the appropriate countermeasures for its minimisation. Work involved collection of liquid steel samples from the onlineargon purging (OLP) station, LF and tundish using a specially designed large size sampler and the routine lollipop samplers. Further liquid steel samples were subjected to inclusion characterisation using scanning electron microscope and energy dispersive spectroscopy (SEM-EDS) and total oxygen measurements. Deposited clog materials from several SENs were also collected and examined for identifying various clogging agents and their possible origin in the upstream steelmaking processes. Finally, plant trials were conducted with modified liquid steel deoxidation practices and improvement in casability was evaluated on the basis of the observed inclusion characteristics and corresponding NCI values of various heats in the casting sequence.

\section{Experimental}

Figure 1 schematically describes the outline of the standard operating procedure (SOP) adopted for the production of low carbon Al killed steel. Depending on the specification of steel grades (e.g. a typical specification of the grade is listed in Table 1) combination of aluminium and different types of ferroalloys are added to the liquid steel along with lime in proper sequence during their ladle treatment. In the present work, for identification of inclusions characteristics at different stages of processing, liquid steel samples were collected using the routine lollipop and a specially designed large sampler before and after OLP and LF treatments, and from the tundish during casting. Design of the special sampler is shown in Figure 2. After taking the liquid steel sample using large sampler, it was sliced into two halves by cutting centrally along the longitudinal as well as transverse directions as shown in Figure 3. The shrinkage cavity containing upper portion of the sample was discarded and only its lower sound portion (Figure $3 b$ ) was used for inclusion characterisation. Characteristics of inclusions in liquid steel samples were examined using SEM-EDS [10].

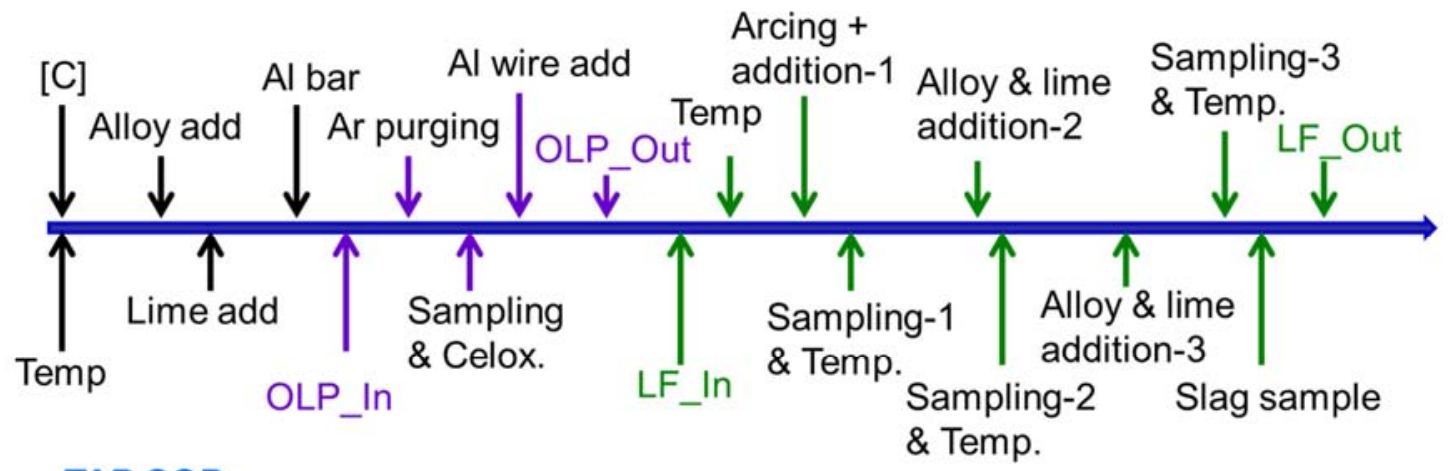

TAP SOP:

1) $\mathrm{HCFeMn}+\mathrm{MCFeMn}$

2) Mn metal

3) $\mathrm{SiMn}$

4) Al notched bar

5) Lime
OLP SOP:

1) Ar purging

2) Al wire addition
LF SOP:

1) $\mathrm{HCFeMn}+\mathrm{MCFeMn} / \mathrm{Mn}$ metal/SiMn

2) Al cube

3) Lime

4) $\mathrm{FeNb}$

Figure 1. Schematic SOP adopted to produce of low carbon low silicon steel. 
Table 1. Chemical specification of a typical low carbon low silicon grade of steel.

\begin{tabular}{llllllll}
\hline $\mathbf{\%} \mathbf{C}$ & $\mathbf{\%} \mathbf{M n}$ & $\mathbf{\%} \mathbf{S i}$ & $\mathbf{\% ~ A l}$ & $\mathbf{\% ~ S}$ & $\mathbf{\%} \mathbf{P}$ & $\mathbf{\%} \mathbf{~ N b}$ & {$[\mathbf{N}], \mathbf{p p m}$} \\
\hline $0.07-0.1$ & $1.0-1.5$ & $\cong 0.05$ & $0.021-0.04$ & $0-0.01$ & $0.01-0.015$ & $0.004-0.01$ & $<90$ \\
\hline
\end{tabular}

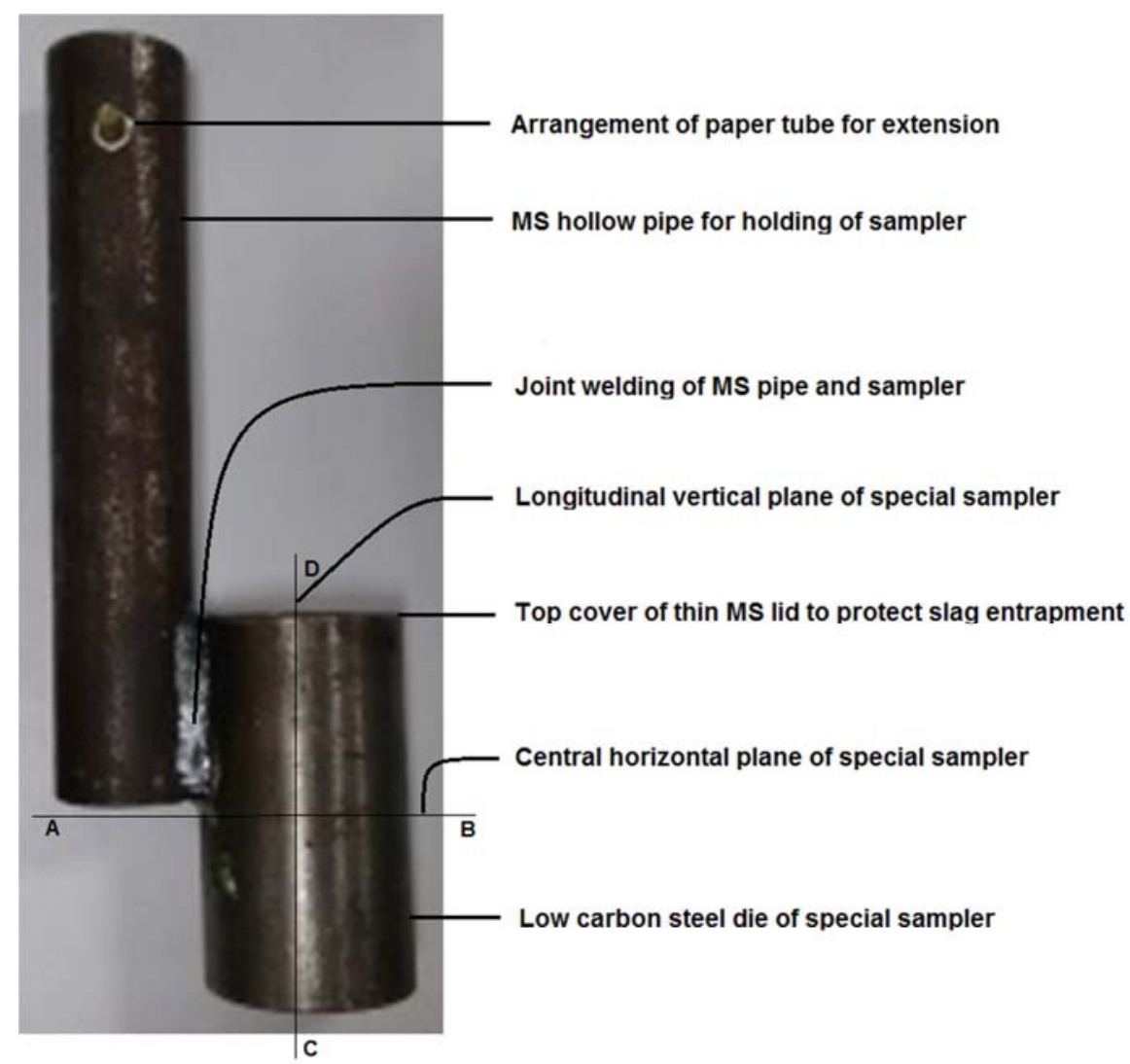

Figure 2. Design of large liquid steel sampler used in the present work.
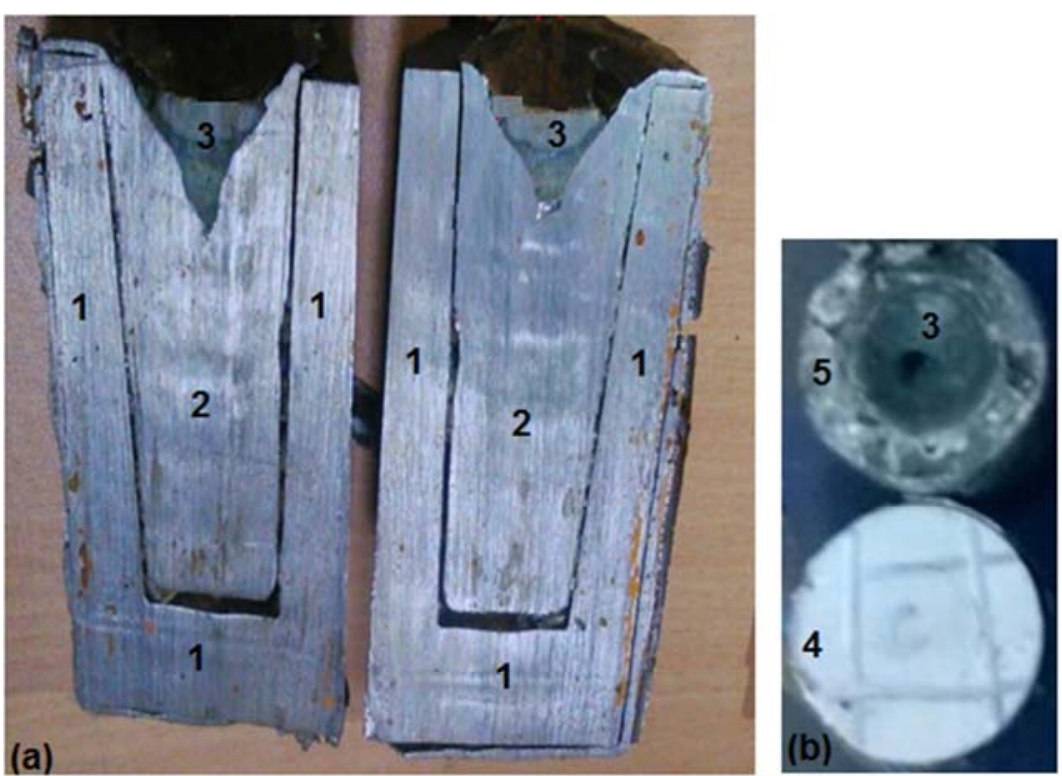

1 Low carbon steel die of special sampler

2 Longitudinal vertical cross section of special sample

3 Pipe formation during sampling of liquid steel

4 Upper surface of central horizonal cross section of sample

5 Top portion of central horizonat cross section of sample

Figure 3. Liquid steel sampling using large sampler (a) central longitudinal slice (b) transverse section. 
After completion of the casting sequence the used SENs were collected to examine the nature of inclusions in the deposit materials using SEM-EDS. Collected SENs after casting were broken and the deposited clog material were taken from its bottom and port areas. Samples were considered from various locations of the clog deposits and the natures of inclusions were identified. Subsequently, to measure the process the different plant trials were carried out for several casting sequences using different deoxidation practices. During the trials, the details of upstream liquid steel processing and corresponding casting data were collected. Also, NCI for a complete casting sequence was examined for evaluating their casting performances. Methodology of NCI calculation has already been reported elsewhere [9].

For the quantification of steel cleanliness, total oxygen content of liquid steel $\mathrm{T}[\mathrm{O}]$ was measured for the samples collected after each ladle treatment stage. Samples for this measurement were taken from the routine lollipop samples of liquid steel. The central thick portion of the lollipop was cut into 3 pieces and cylindrical samples of $5 \mathrm{~mm}$ diameter and 8 $\mathrm{mm}$ length were made. Subsequently the cylindrical samples were subjected to fine grinding and polishing. Weight of cylindrical samples ranged between $0.5-1.0 \mathrm{~g}$. For avoiding any contact with air prior to test those samples were immediately dipped into acetone and stored in amber colour glass bottles. The combustion analysis of the sample was done within two hours of the polishing in order to prevent oxygen pickup at the surface of the sample. During the combustion analysis, if the first two values measured for the total oxygen content were within 4-5 ppm of each other, their average was taken as the final $\mathrm{T}[\mathrm{O}]$ value for that sample, otherwise the third piece of that sample was analysed. If all the three values were within $10 \mathrm{ppm}$ of the mean value, the average of three was taken as final value for that sample. However, if there was one reading exceedingly higher than the other two, this reading was discarded and the average of the other two reading was taken as final $\mathrm{T}[\mathrm{O}]$ value. The exceedingly high reading, whenever it occurred can be explained by taking into consideration the possibility of internal porosity in the sample which were not apparent by the visual inspection of the sample.

\section{Results and Discussion}

\subsection{Examination of Deposited SEN Clog Materials}

Visual examination of used several alumina graphite SEN after casting revealed that its barrel was almost clean and practically free from any alumina build up. However, most of the alumina deposition took place around the bottom of the SEN (Figure 4). Bulk of the alumina deposit consisted of friable chalky alumina particles. Samples of alumina build up were collected from the various locations of the deposits and examined using SEM-EDS. In general, coral shaped clusters of pure alumina and platy spinel $\mathrm{MgO} \cdot \mathrm{Al}_{2} \mathrm{O}_{3}$ particles were observed along with small quantity of other inclusions in the nozzle deposits. Inclusion particles were heterogeneously distributed throughout the deposits. Bulk of the deposits consisted of round and angular pure alumina particles as shown in Figure 5. Commonly, such angular alumina particles form due to late addition of aluminium to the already deoxidised liquid steel [11, 12]. Besides these, globules of iron particles were also observed which were entrapped in the alumina clusters at few locations (Figure 6). Entrapped iron particle took the globular shape essentially due to the non-wetting characteristics of alumina towards liquid steel. Non-wetting alumina essentially prevented entrapped liquid steel from spreading in the inter-particle voids of the clusters. That is why entrapped liquid steel particles got locked and froze within the clusters (as round particles) due to insufficient capillary force available to drive/ooze them out [13-15]. As already mentioned, bulk of the inclusion deposits consisted mostly of coral shaped clusters of pure alumina $\left(\mathrm{Al}_{2} \mathrm{O}_{3}\right)$ and spinel $\left(\mathrm{MgO} \cdot \mathrm{Al}_{2} \mathrm{O}_{3}\right)$ inclusions, essentially indicating these two as the prime clogging agents in the current ladle deoxidation practice [1619]. Common physical characteristics of above clogging agents are presented in Table 2.

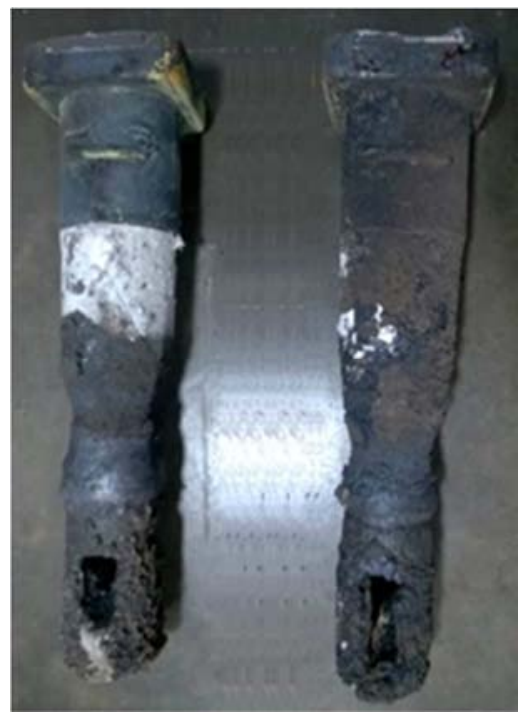

(a)

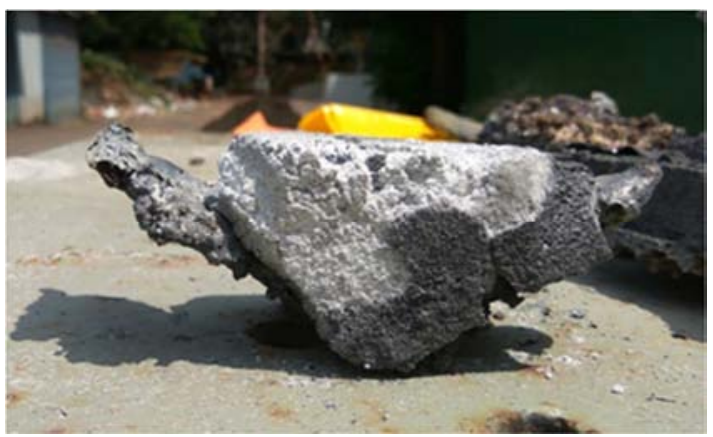

(b)

Figure 4. Sample collections (a) used SENs after completion of casting sequence and (b) deposited materials collected from the bottom of used SEN. 

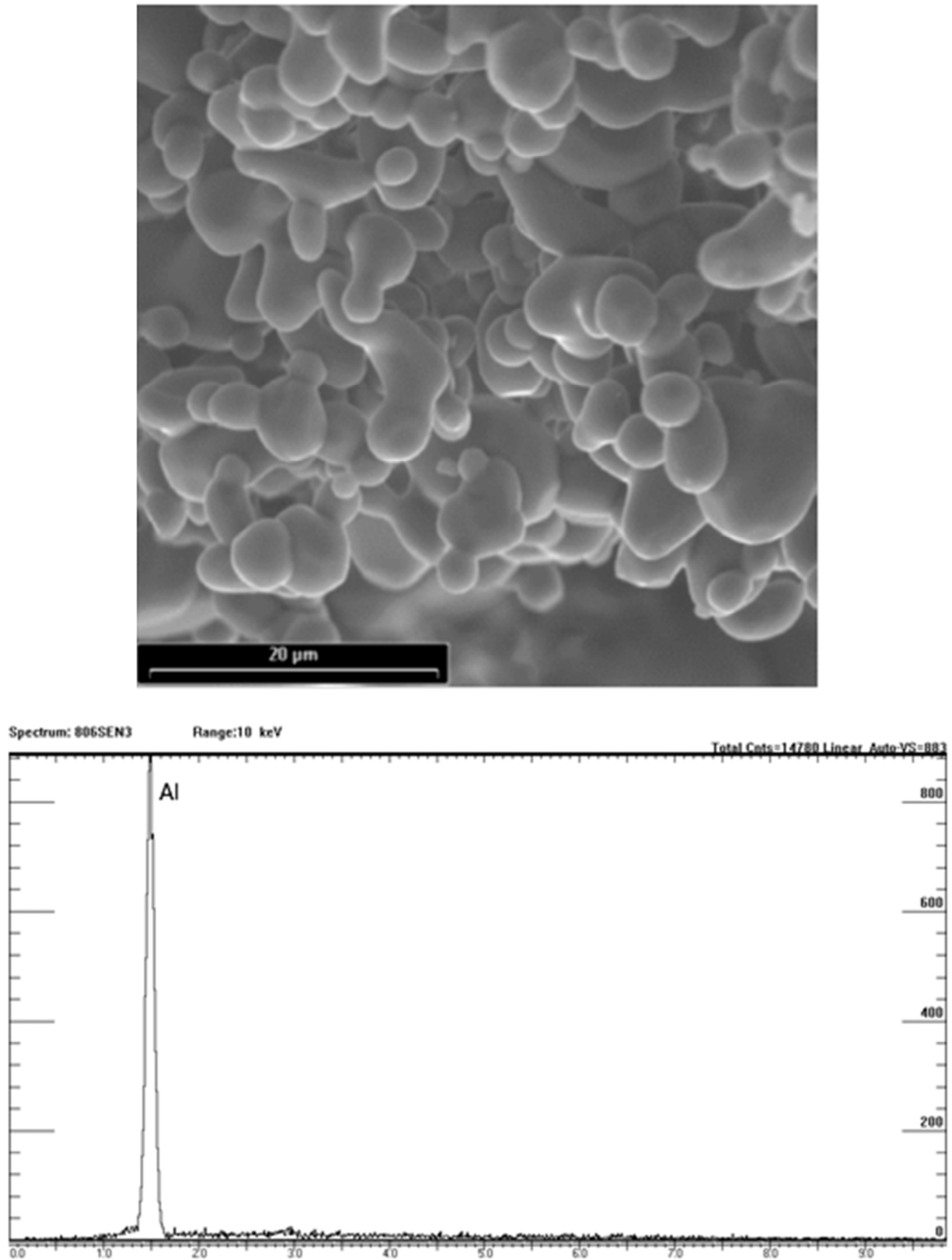

(a) 

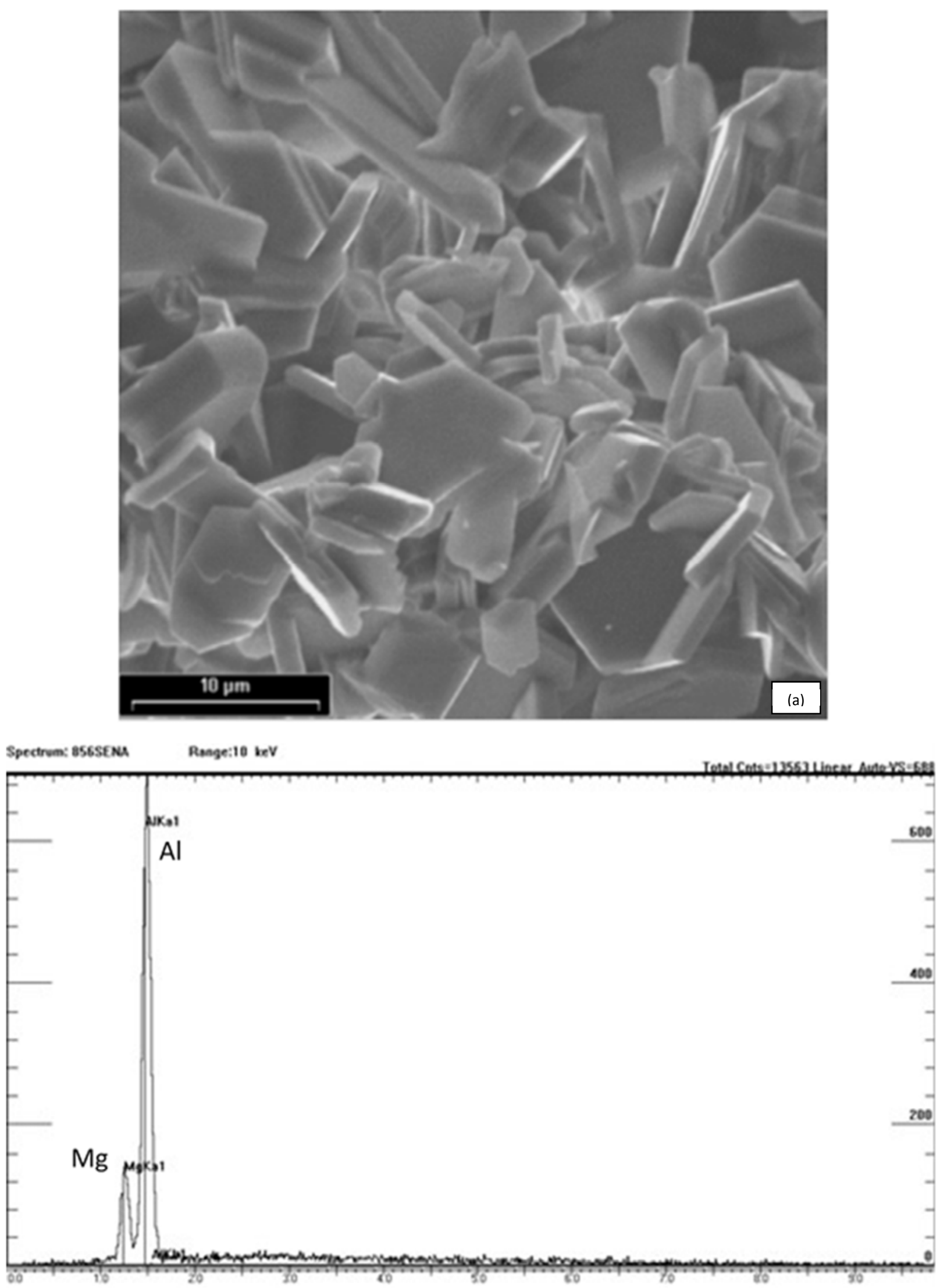

(b)

Figure 5. Pure alumina clusters (a) and the spinel (b) found in the SEN clog deposits. 


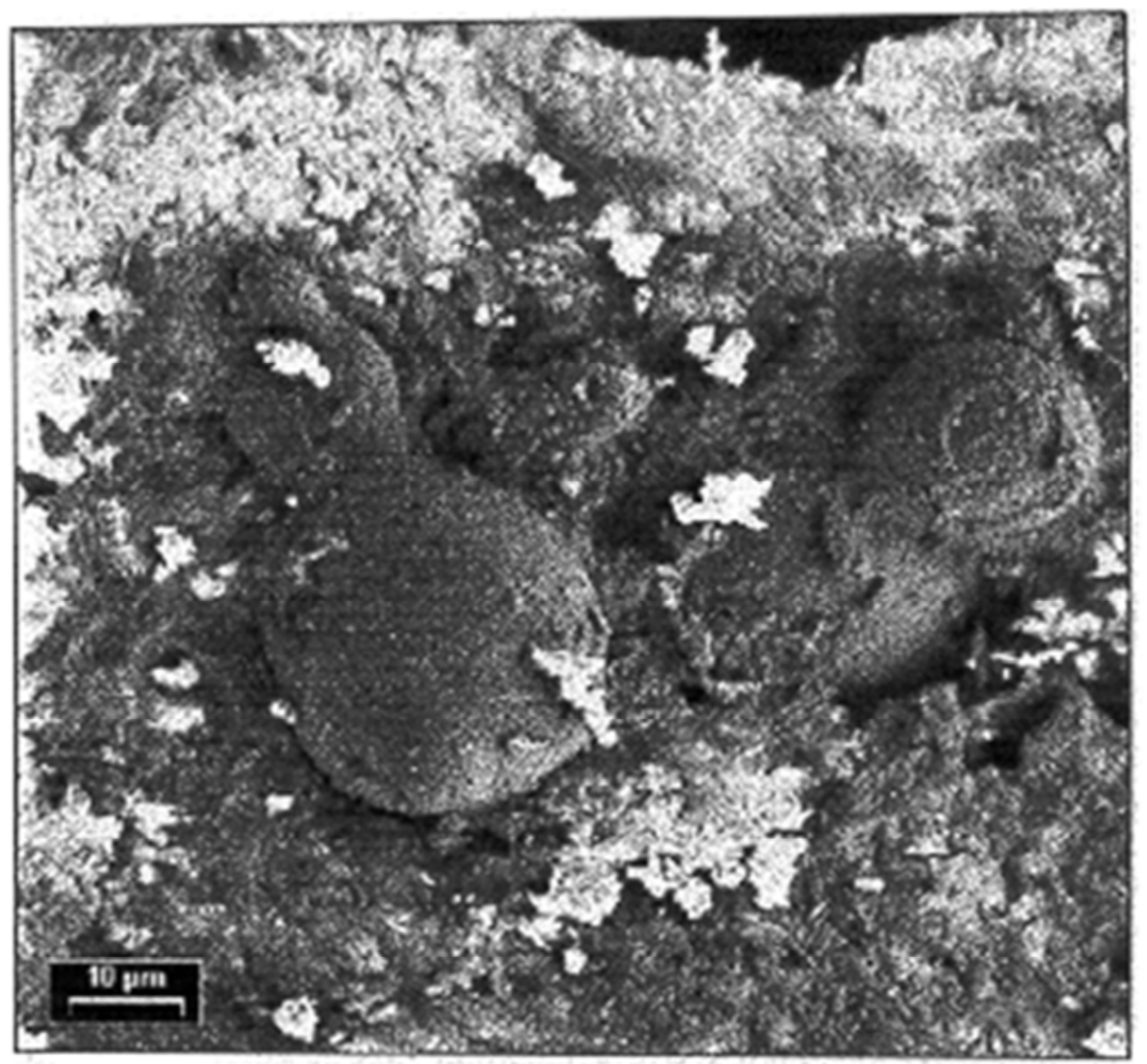

Figure 6. Entrapped globular iron particles found in the SEN clog deposits.

Table 2. Characteristics of common clogging agents in liquid Al-killed steel.

\begin{tabular}{|c|c|c|}
\hline Parameters & Alumina, $\mathrm{Al}_{2} \mathrm{O}_{3}$ & Spinel, $\mathrm{MgO}_{x} \mathrm{xAl}_{2} \mathrm{O}_{3}$ \\
\hline State at $1600^{\circ} \mathrm{C}$ & Solid & Solid \\
\hline Surface tension (w.r.t. & Non-wetting & Non-wetting \\
\hline liquid iron at $1600^{\circ} \mathrm{C}$ ) & $\theta_{\mathrm{c}} \sim 140^{\circ}$ & $\theta_{\mathrm{c}} \sim 120^{\circ}$ \\
\hline Clustering tendency & Strong tendency & Weak tendency \\
\hline Floatation in liquid steel & $\begin{array}{l}\text { Easier } \\
\text { (for large clusters) }\end{array}$ & Difficult \\
\hline Entrapment of liquid steel & $\begin{array}{l}\text { Liquid steel repellant; bulk of alumina } \\
\text { deposit practically free from frozen metal }\end{array}$ & $\begin{array}{l}\text { Liquid steel repellant; clustures of spinal also practically free from frozen } \\
\text { metal }\end{array}$ \\
\hline Presence & $\begin{array}{l}\text { Present in all liquid steel samples from LF, } \\
\text { Tundish \& SEN clog }\end{array}$ & Present in all LF, tundish \& clog samples \\
\hline Source & $\begin{array}{l}\text { Unfloated products of deoxidation \& } \\
\text { reoxidation }\end{array}$ & $\begin{array}{l}\text { Exclusively forms if } \mathrm{Mg} \text { is present in liquid steel (as low as } 0.5 \mathrm{ppm} \mathrm{Mg} \text { is } \\
\text { sufficient to form spinel) } \\
\text { Reaction between dissolved [Al] in liquid steel \& } \mathrm{MgO} \text { present in ladle lining } \\
\text { Prolonged treatment \& holding time (in } \mathrm{MgO} \text { lined ladle) } \\
\mathrm{Mg} \text { present in ladle additions } \\
\text { Overkilling of } \mathrm{MgO} \text { containing ladle slag (very low slag } \mathrm{FeO} \text { ) }\end{array}$ \\
\hline
\end{tabular}

\subsection{Inclusion Characteristics of Liquid Steel}

Table 3 shows the distribution of total inclusion area percentage in liquid steel samples at different stages of liquid steel from ladle treatment up to casting. In order to ensure that inclusions measured in the laboratory must represent fairly well its content in total volume liquid present in the ladle, all samples were collected using the large size special samples. It was observed that most of oxide and sulphide NMI were present in almost all the samples taken before and after LF treatment in addition to some slag entrapment observed in the tundish. Alumina and spinel inclusions were mostly observed in all liquid steel samples. Isolated angular alumina particles (size $<5 \mu \mathrm{m}$ ) were more frequently seen. Few compact alumina clusters were also present in some of those samples. 
Table 3. Variation of amount of inclusions from ladle furnace $(L F)$ to tundish.

\begin{tabular}{|c|c|c|c|}
\hline \multirow{2}{*}{ Type of inclusions observed } & \multicolumn{3}{|c|}{ Total area fraction of inclusion, percent } \\
\hline & before LF treatment & after LF treatment & Tundish \\
\hline Alumina-titania & 0.00188 & 0.00138 & 0.00053 \\
\hline Alumina & 0.00164 & 0.00191 & 0.00123 \\
\hline $\mathrm{MnS}$ & 0.00285 & 0.00406 & 0.00695 \\
\hline MnS-associated with alumina & 0.00698 & 0.00567 & 0.00699 \\
\hline $\mathrm{MgO}-\mathrm{Al}_{2} \mathrm{O}_{3}$ & 0.00024 & 0.00475 & 0.00145 \\
\hline Complex Ca-Al-Si-Mn-O inclusion (slag) & - & - & 0.002 \\
\hline
\end{tabular}

Figure 7 shows a typical alumina clusters. In addition, some exclusively reoxidation product $\mathrm{Al}_{2} \mathrm{O}_{3} \cdot \mathrm{TiO}_{\mathrm{x}}$ was found in liquid steel after OLP treatment. $\mathrm{Al}_{2} \mathrm{O}_{3}$ inclusions formed first, causing local depletion of $\mathrm{Al}$ and supersaturation of $\mathrm{Ti}$ followed by reaction $\mathrm{Al}_{2} \mathrm{O}_{3}(\mathrm{~s})+[\mathrm{Ti}]+\mathrm{x}[\mathrm{O}]=\mathrm{Al}_{2} \mathrm{O} 3 . \mathrm{TiO}_{\mathrm{x}}$ (s) and $\mathrm{Al}_{2} \mathrm{O}_{3} \cdot \mathrm{TiO}_{\mathrm{x}}$ got precipitated over preexisting solid inclusions like alumina and spinel [20 - 24]. It has been reported [25] that the formation of MnS type of inclusion in common low carbon Al killed steel would be possible only during the solidification of liquid steel in the mould during solidification where the concentration of [S] in the mushy zone gradually increases and reach its saturation level. Presence of MnS inclusion in the present study could be due to relatively slow liquid solidification in the thick samplers.
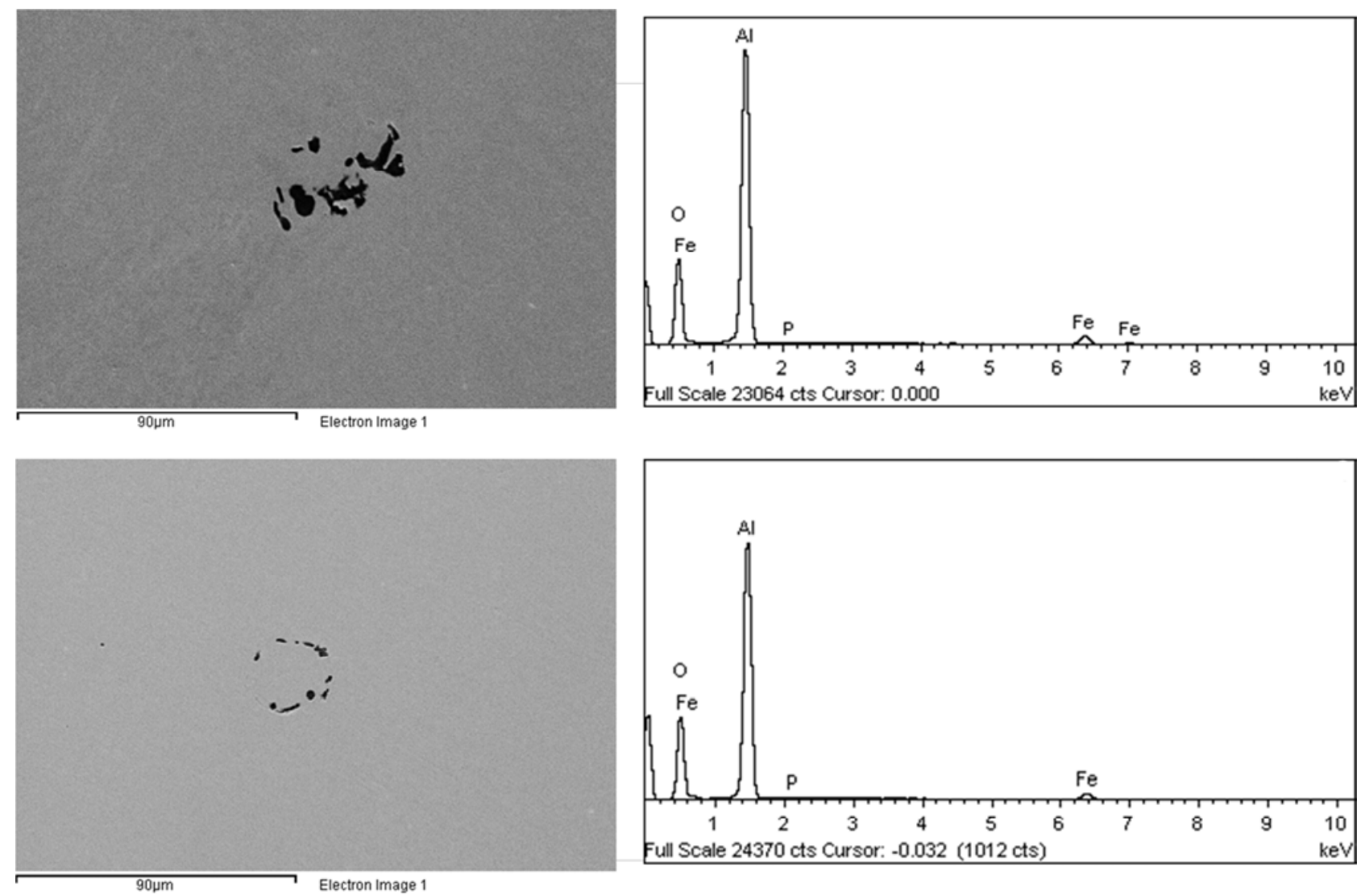

Figure 7. SEM-EDS analysis of alumina clusters found in liquid steel samples.

$\mathrm{Al}_{2} \mathrm{O}_{3} \cdot \mathrm{MgO}$ (Spinel) was considered to originate from the side reactions especially from ladle refractory lining, top slag and/or traces of $\mathrm{Mg}$ content of aluminum used for the liquid steel deoxidation. In the present work, samples taken after the ladle treatment contained exogenous $\mathrm{CaO}-\mathrm{SiO}_{2}-\mathrm{Al}_{2} \mathrm{O}_{3}$ inclusions containing small quantity $\mathrm{MgO}$ and $\mathrm{MnO}$ which were possibly originated from the slag entrapment. These inclusions were liquid initially and got solidified on cooling during the sampling process. In addition, some $\mathrm{MnO}-\mathrm{SiO}_{2}$ containing only a small quantity of $\mathrm{Al}_{2} \mathrm{O}_{3}$ inclusions were observed in few cases. Few isolated $\mathrm{MnS}$ particles or in association with other oxides were also found, which formed exclusively during the last stage of solidification, were also present in the liquid steel samples. Entrapped slag particles of different sizes were found almost randomly distributed in various samples (Figure 8). Spinel normally forms when liquid steel contains dissolved magnesium in trace quantity. Thermodynamically, as low as $0.5 \mathrm{ppm}[\mathrm{Mg}]$ in liquid aluminium killed steel is sufficient enough to produce spinel inclusion [26, 27]. Spinel inclusion has a relatively weak floatability in the liquid steel. Therefore, the best solution is to avoid spinel formation by eliminating all possible sources of metallic magnesium in liquid steel. 

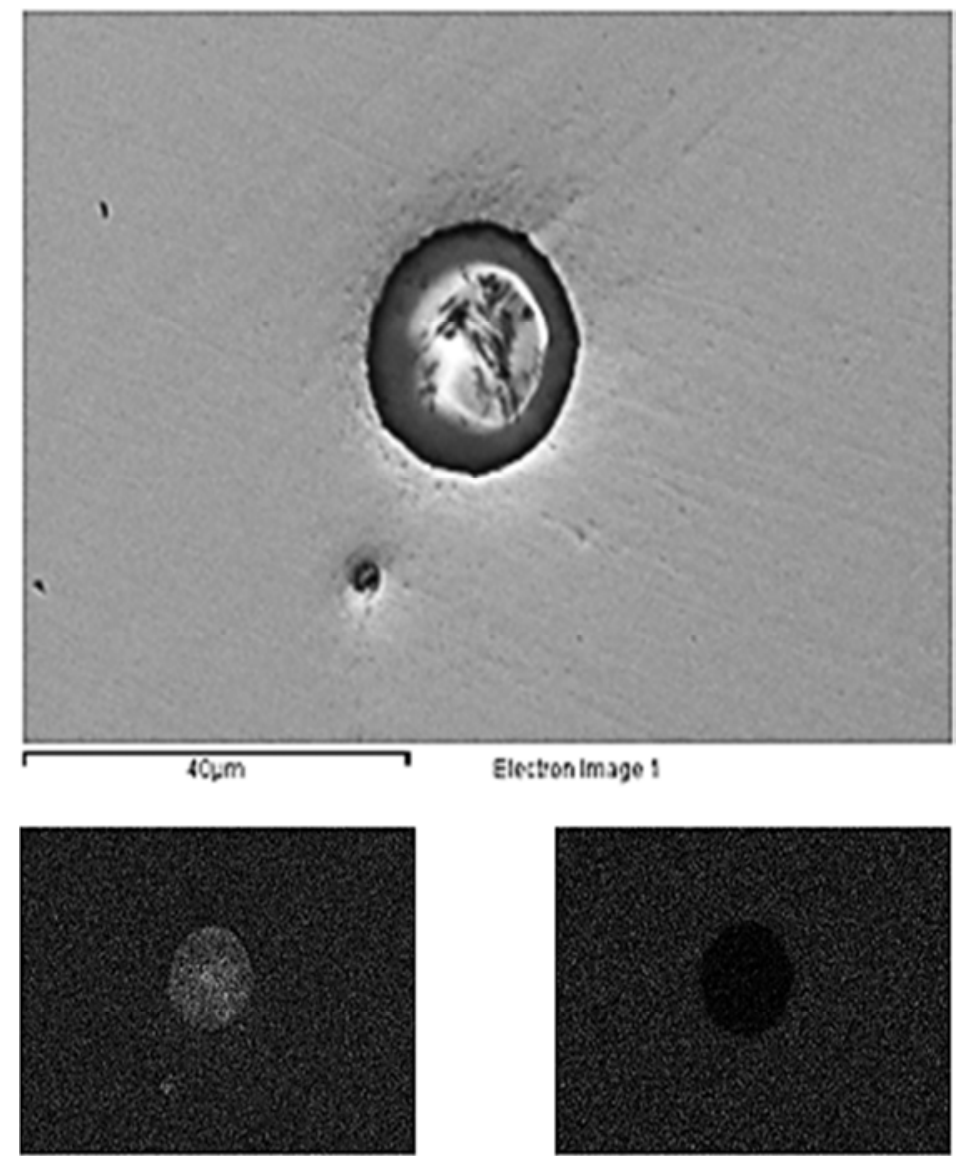

OKa1
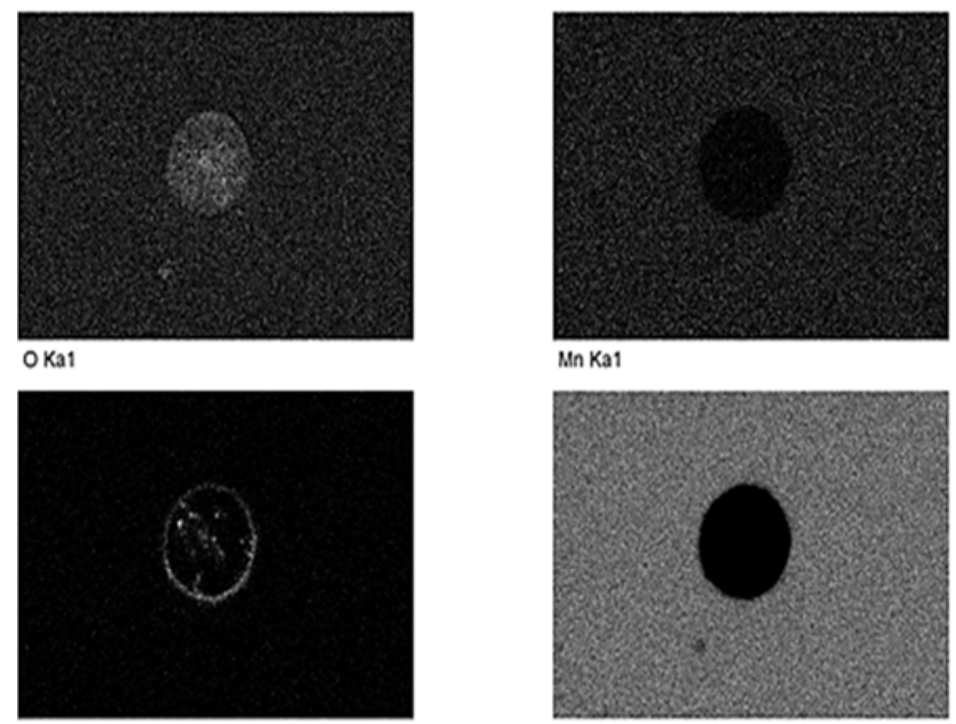

Mn Ka1

s Ka1
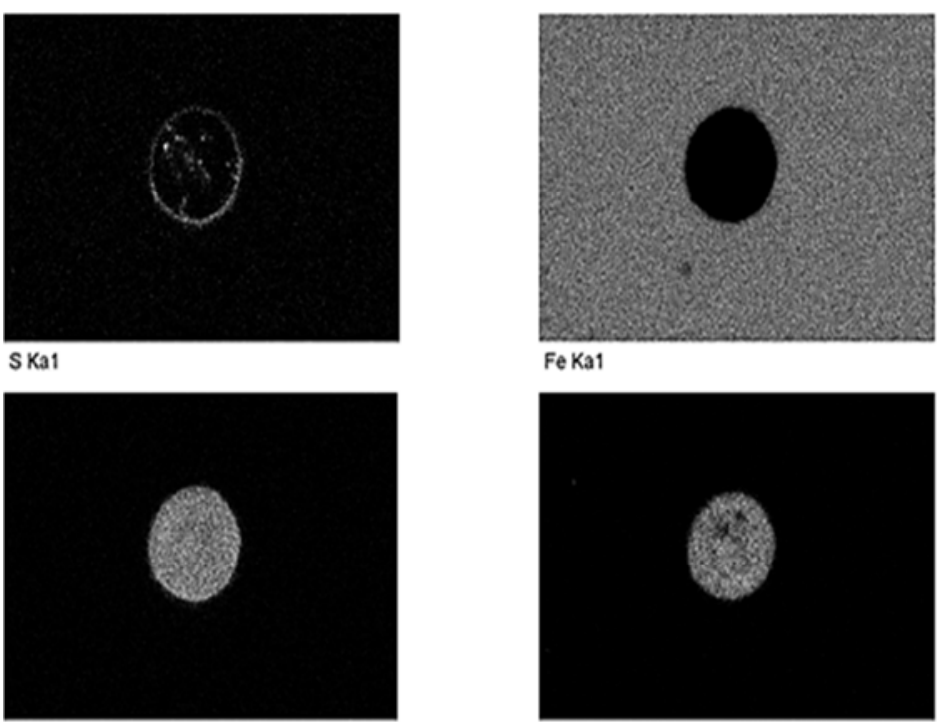

Ca Ka1
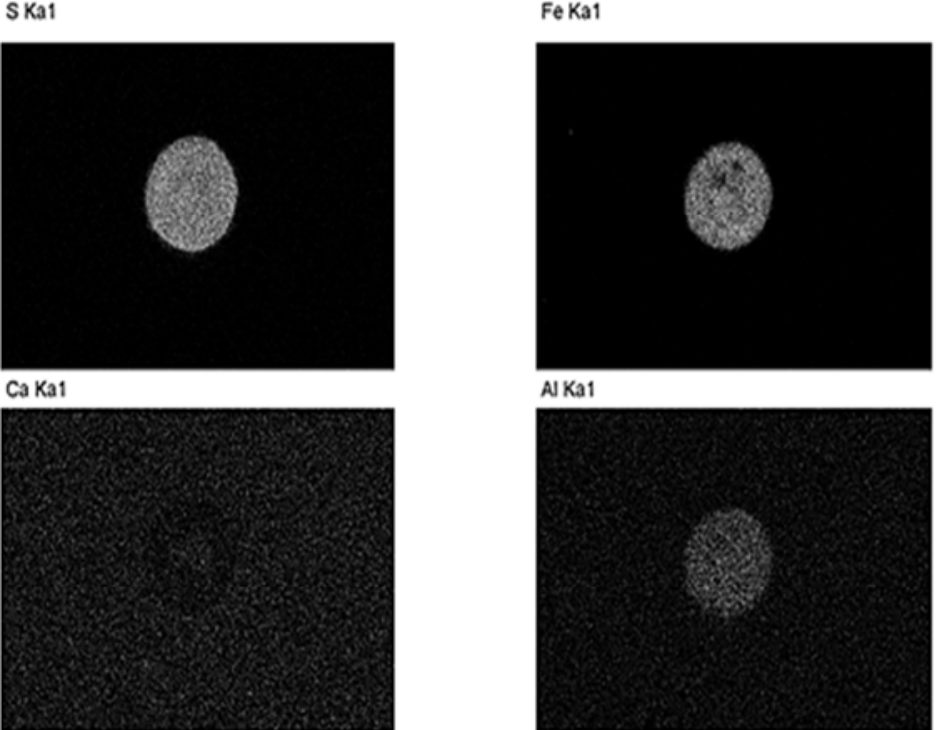

Al Ka1

SiKa1

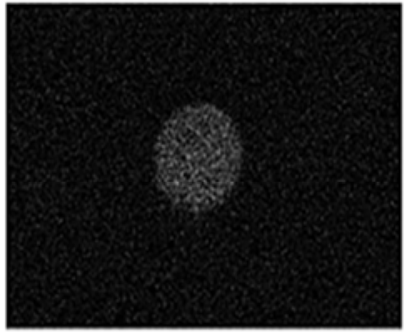

Mg Ka1_2

Figure 8. X-ray map of constituent elements of a typical slag entrapment. 


\subsection{Inclusion Size Distribution of Liquid Steel}

Size distributions of inclusions were measured in order to find out their relative populations in the liquid steel samples. Size distribution of NMI in liquid steel at different stages from the ladle treatment to caster is shown in Figure 9. It can be seen that the smaller inclusions less than $5 \mu \mathrm{m}$ were relatively abundant in all samples. Most of the inclusions in this range were found to be primarily the residual deoxidation product. Reoxidation inclusions of sizes ranging from about 2-10 $\mu \mathrm{m}$ were also observed. In comparison, there were only a few large size inclusions. Even then their relative population was small but such inclusions are considered to be more detrimental to steel properties. They occurred as clusters, aggregates, and sometimes as dendrites. However, in some cases slag entrapment as large as 300 microns has also been observed in cast slab samples [28].

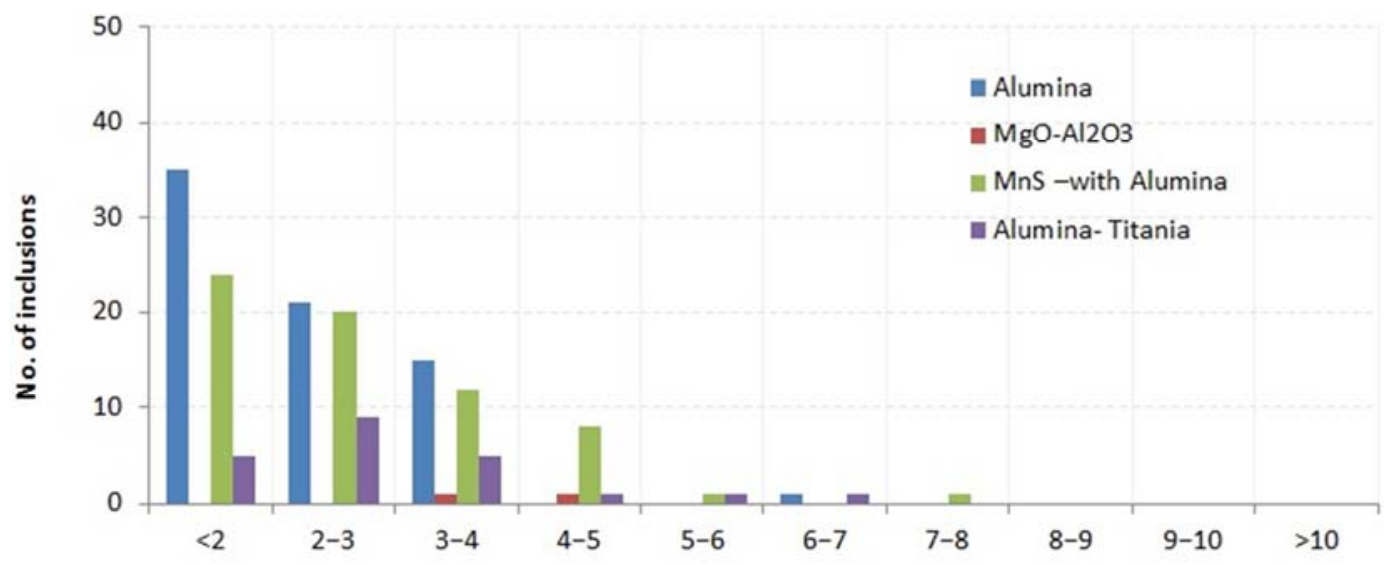

(a)

Size, $\mu \mathrm{m}$

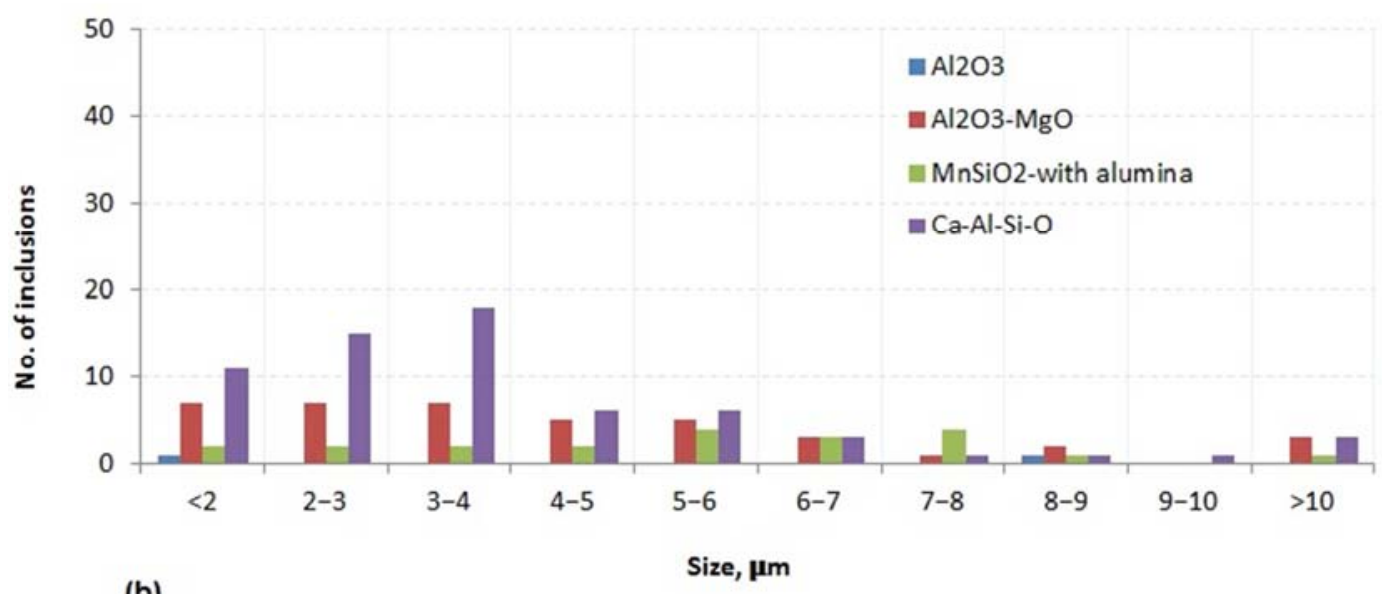

(b)

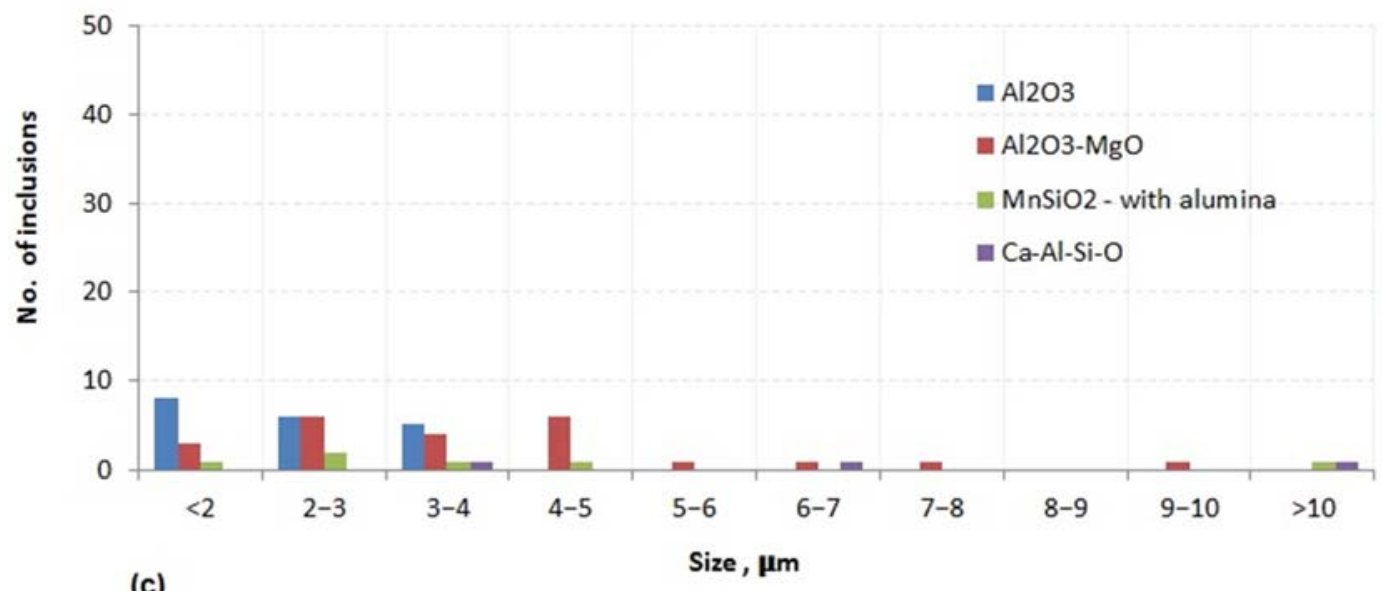

Figure 9. Inclusion size distribution of a typical heat at different stages at (a) LF before treatment, (b) LF after treatment and (c) tundish. 


\subsection{Plant Trials and NCI Distribution}

As already indicated above, nozzle clogging during casting was mostly due to presence of large number of unfloated fine alumina and spinel inclusions in the liquid steel, therefore attempts have been made to minimise their population by taking measures in the upstream liquid steel processing and handling operations. In the current practice, low carbon $\mathrm{Al}$ killed steels are produced by using step wise deoxidation process. Initially preliminary deoxidation is being carried out by adding commercial aluminium bars to the crude steel during tapping from the vessel. Further, $\mathrm{Al}$ wire is injected at
OLP station after that liquid steel is sent to the LF for further treatment. In the LF depending upon the aluminium content of further $\mathrm{Al}$ addition to liquid steel is made. In the present work, plant trials were conducted for with modified deoxidation practice in which most of the aluminium addition were made during the vessel tapping and only a small quantity of the same was added in the subsequent ladle treatment. Besides this, total lime addition was also reduced as compared to previous practice. Casting performance of all trial heats was evaluated on the basis of observed NCI values. Actions taken in the modified practices (trials) are shown in Table 4.

Table 4. Additions during ladle treatment of liquid steel.

\begin{tabular}{lllll}
\hline \multirow{2}{*}{ Ladle additions } & \multirow{2}{*}{ Old practice } & \multicolumn{2}{l}{ Modified practice } & \\
\cline { 3 - 5 } & & trial 1 & trial 2 & measures taken for optimisation \\
\hline Lime during tapping, $\mathrm{kg}$ & $500-800$ & $500-600$ & $500-600$ & limit of maximum addition reduced by 200 kg; range narrowed down \\
Lime in LF, kg & $300-500$ & $400-500$ & $400-500$ & lower limit increased by 100 kg; addition range restricted \\
Al bar at tapping, kg & $200-400$ & $300-320$ & 320 & reduced \\
Al-wire before LF treatment & $100-150$ & $0-60$ & 0 & as needed \\
\hline
\end{tabular}

The overall NCI distribution in different heats of two trial casting sequences has been compared with the base data (existing plant operation) in Figure 10. In general, most of the trial heats exhibited relatively lower NCI values as compared to the previous practice (Figure 10). Higher aluminium addition during vessel tapping and only a small addition in subsequent LF treatment gave relatively less clogging problem during casting. This has been attributed to the generation of mostly easily floatable large alumina particles due to relatively higher oxygen content of liquid steel during tapping and reduced generation of problematic finer alumina inclusions subsequently. Avoiding the late aluminium addition prevented generation problematic fine alumina inclusions. During trials, final slag chemistry in the LF remained almost same. With these modified deoxidation process, on an average about 60 percent drop in NCI was found in most of the trial heats (NCI $\geq 0.66$ for bad heats in previous case and $\mathrm{NCI} \cong 0.26$ for good heats) during casting.

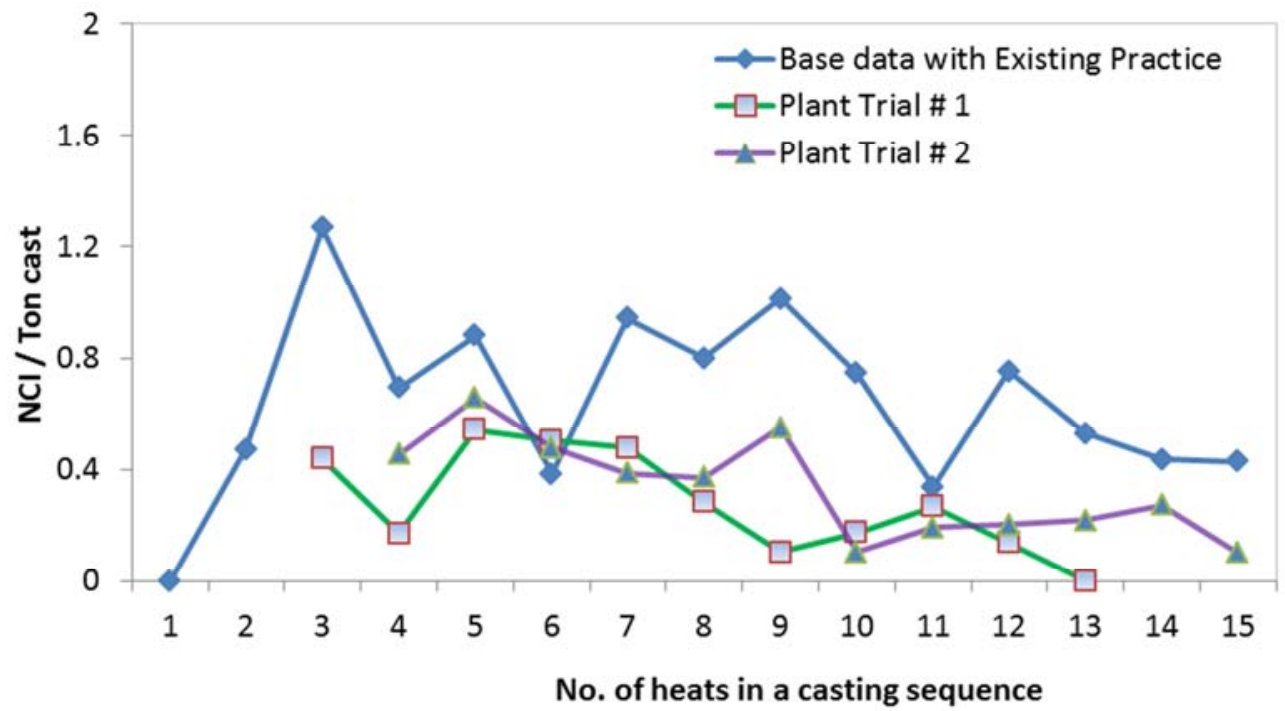

Figure 10. Comparison of NCI performance on deoxidation practices against each plant trial over a complete casting sequence

Figure 11 presents a typical online distribution of NCI (blue line) in different heats for a trial casting sequence, where less lime addition was made at the liquid steel tapping and more of it was added in the subsequent LF treatment. It can be seen that the number of argon flushing through stopper rod (auto and manual) was significantly higher than that of a general casting operation. Slag characteristics plays important role in absorbing the floated alumina from the liquid steel. In the plant trials slag formation was modified by minimizing the quantity of lime addition during tapping. 

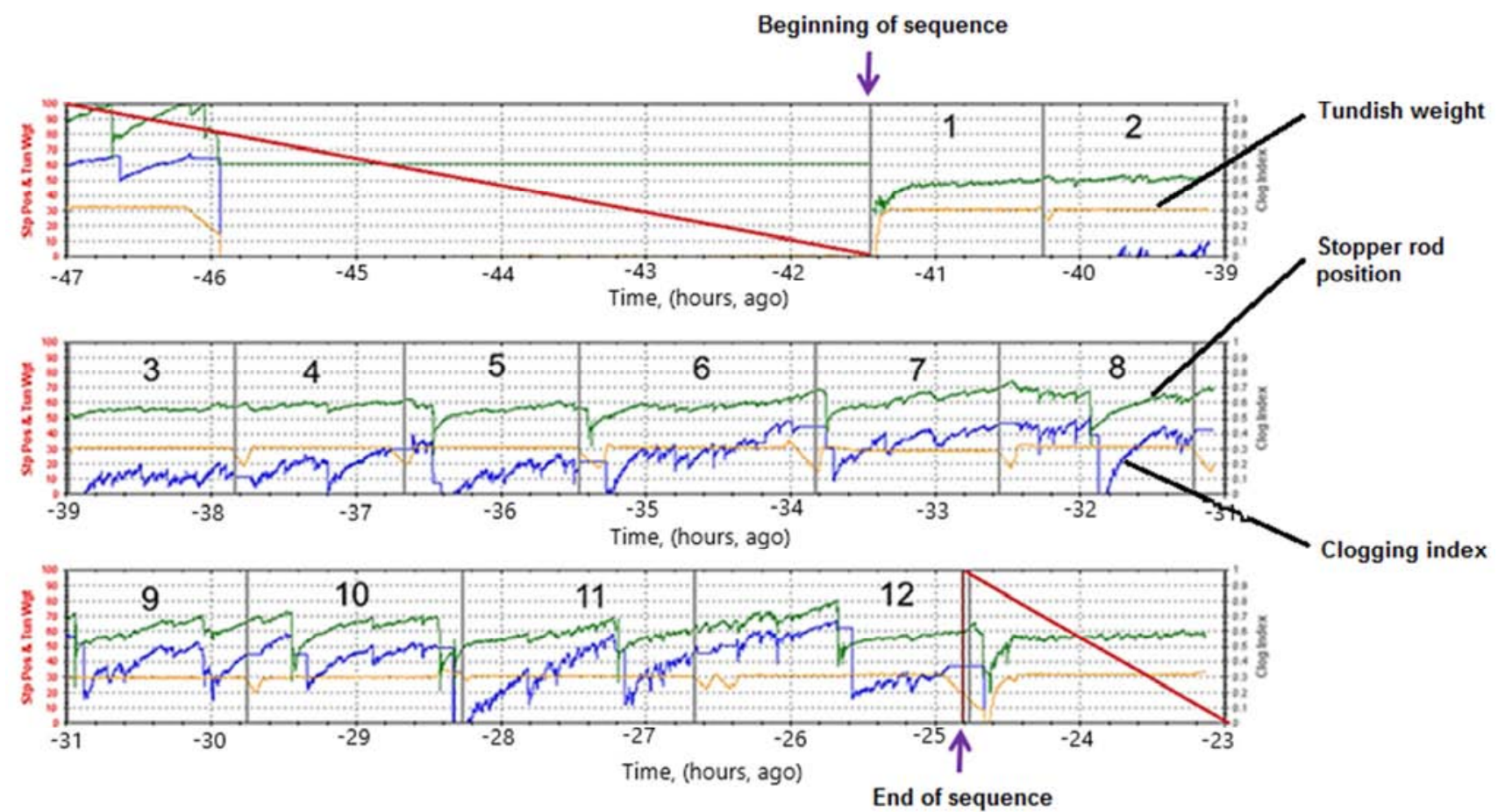

Figure 11. On-line data of stopper rod movement, nozzle clogging index and tundish weight with progress of casting in a trial casting sequence of 12 heats.

Figure 12 shows the major constituents of the steelmaking slag at different stages of ladle treatment. It can be observed that $\mathrm{CaO}$ content in the slag after OLP treatment was about $45 \%$ in comparison to about $55 \%$ after LF treatment. The excess or insufficient lime may also be detrimental for clogging [29]. Lime addition during liquid steel tapping (OLP) and LF treatment is shown in Figure 13. It can be observed from both the figures (a) and (b) that there were a wide range of variations (about $400-1400 \mathrm{~kg}$ per heat) of total lime additions during Tap and LF treatment. In addition, the contributions of lime additions at Tap and LF for such grades were not consistent. The ratios of tap to LF additions per heat were varied from 0.5 to 2.0 (can be seen in 'b' part of the figures). Such types of variations of lime additions may cause the performance of alumina holding capacity of the slag which may affects the inclusion floatation and hence affects NCI performance during the casting operations.

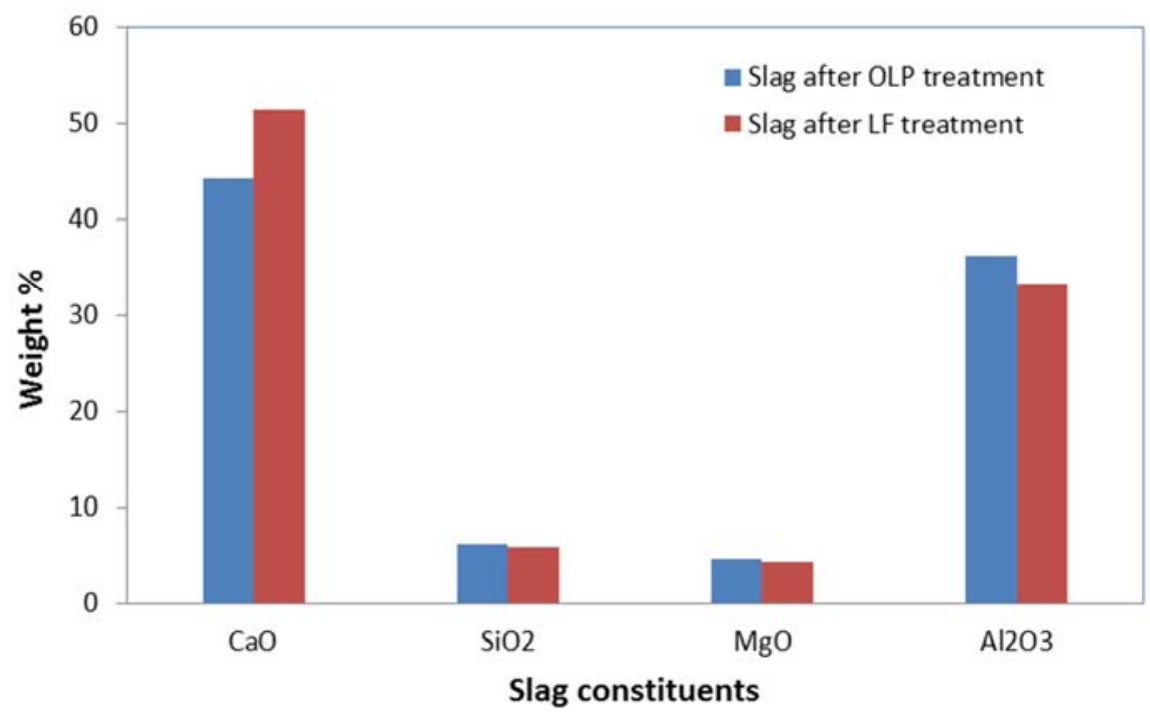

Figure 12. Main constituents of ladle slag after OLP and LF treatments of liquid steel. 


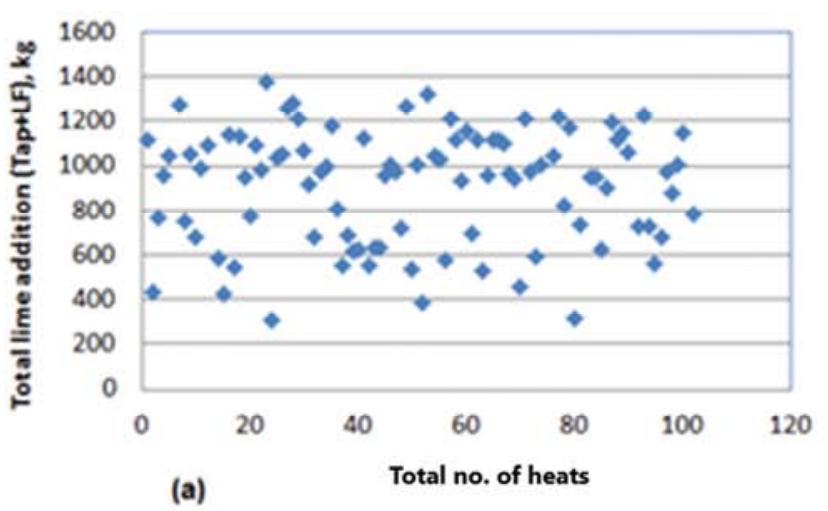

Figure 13. Pattern of lime addition during liquid steel treatments: (a) total lime at Tap and LF and (b) ratio of lime Tap to LF.

\subsection{Steel Cleanliness}

Figure 14 shows the distribution of $\mathrm{T}[\mathrm{O}]$ of liquid steel at OLP and Tundish. In Al-killed steel with $\mathrm{T}[\mathrm{O}]$ content of 30 $\mathrm{ppm}$, the number of $2 \mu \mathrm{m}$ size inclusions have been estimated $[30,31]$ to be around $4.5 \times 10^{12}$, which is considerably large enough to clog the nozzle. Therefore, it appears that even in steels with very high cleanliness level (e.g., T [O] 10 ppm), there still have enough inclusions to clog the nozzle. As a matter of fact, bulk of the nozzle deposit consists of only fine (2-5 $\mu \mathrm{m})$ alumina particles, which again confirm the role of microinclusions on nozzle clogging. As discussed already, overall steel cleanliness was measured through its total oxygen content using LECO (TC600) oxygen determinator. T [O] content of steel is summation of dissolved oxygen and the oxygen combined with oxide non-metallic inclusions. In solid steel, dissolved oxygen is practically negligible. Therefore, the measured $\mathrm{T}[\mathrm{O}]$ essential is taken as an indirect measure of the oxide NMI contents of steel. Dissolved oxygen in liquid steel is commonly measured using solid electrolyte sensors (CELOX). In liquid Al-killed steel dissolved oxygen vary between 3-5 ppm (almost constant).

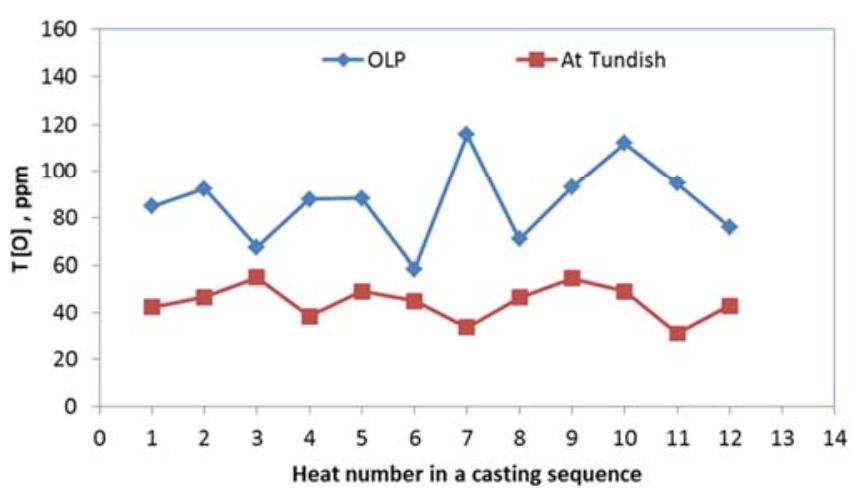

Figure 14. Distribution of T[O] content of liquid steel at OLP and Tundish.

Due to the small population of large inclusions in the steel and the small sample size for $\mathrm{T}[\mathrm{O}]$ measurement (normally $1.0 \mathrm{~g}$ ), it is rare to find a large inclusion in the sample. Even if a sample has a large inclusion, it is likely discounted due to its anomalously high reading. Thus, $\mathrm{T}$ [O] content really

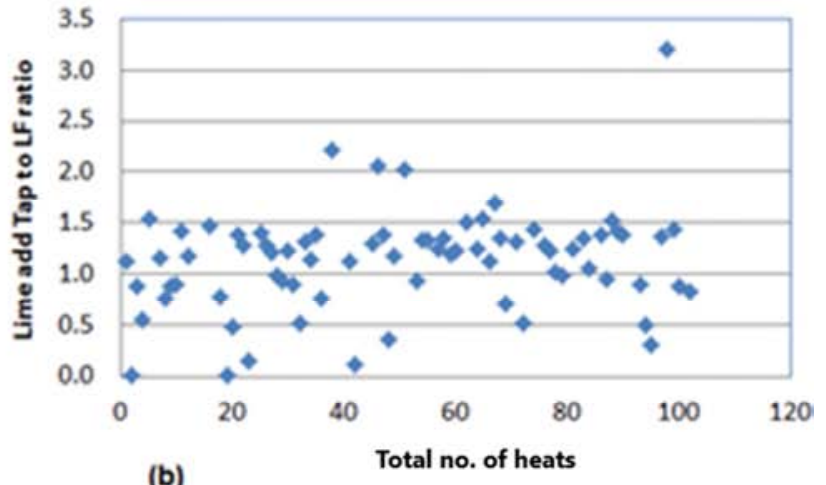

represents the level of small oxide NMI only. A low T [O] content, however, decreases the probability of large oxide inclusions. Clean steel requires control of the size distribution, morphology and composition of oxide NMI in addition to the amount. It can be seen from the figure that $\mathrm{T}$ [O] of liquid steel was found in the range of 60-120 ppm at OLP and 30-55 ppm at tundish of low carbon low silicon grade of steel.

\section{Conclusion}

Slab casting of low carbon and low silicon aluminium killed steel has been quite problematic in comparison to other grades. These grades suffered from undue stopper rod movement and higher mould level fluctuation during casting, leading to significant downgrading of cast slabs. Present work aimed at identifying the potential causes of above and recommends measures to the plant for the improvement. Towards this, samples of clog material from several used SEN were collected along with corresponding liquid steel samples from the tundish and from the ladle after each stage of treatments. Characteristics of the inclusions present in the SEN deposits and liquid steel at LF and tundish were determined using SEM-EDX in order to establish their roles on the observed castability of liquid steel. Most of the inclusion deposition was found at the bottom of SEN (port region). Inclusion deposit consisted of white friable (chalky) material. SEM-EDX examination revealed the clog material contained mostly coral shaped alumina clusters and spinel inclusions along with few globular frozen steel particles inside the deposits. Corresponding liquid steel samples from LF and tundish found to contained large number of finer (less than 5micron size) solid alumina and spinal inclusions. In addition, some reoxidation products and slag entrapments were also observed. Wide variation in the quantity of $\mathrm{Al}$ additions (200-400 kg Al bar during Tap and 100-200 m of Al wire before LF treatment) and lime additions (about 400$1400 \mathrm{~kg}$ per heat of total lime additions during Tap and LF treatment) was observed, particularly during the primary and secondary deoxidation of liquid steel in the ladle. Large addition of aluminium and lime led to poor castability of the steel. All these influencing parameters of ladle additions practice were optimized through several plant trials for better 
castability of liquid steel in terms to lower NCI values during casting operations. Al additions during Tap was reduced to $300-320 \mathrm{~kg}$ and $\mathrm{Al}$ wire feeding was reduced to $0-60 \mathrm{~m}$ at OLP. Similarly, the total lime addition was reduced to 900 $1000 \mathrm{~kg}$. T [O] of liquid steel was found to vary over a wide range (60-120 ppm) just after primary deoxidation during tapping and OLP and after subsequent treatment it was found to decrease up to $30-55 \mathrm{ppm}$ in the tundish.

\section{Acknowledgements}

The author would like to thank Tata Steel to allow this work to publish. Dr. T. K. Roy and Mr. V. Balakrishnan are also acknowledged for helping during sampling through special samplers.

\section{References}

[1] L. Zhang and B. G. Thomas: ISIJ Int., 43(2003), 271.

[2] L. Zhang, X. Wang, K. Cai and B. G. Thomas: Steelmak. Conf. Proc., ISS-AIME, 85(2002), 431.

[3] Y. Hara, A. Idogawa, T. Sakurya, S. Hiwasa and H. Nishikawa: Steelmak. Conf. Proc., Washington, 75(1992), 513.

[4] A. W. Cramb and M. Byrne: Steelmak. Conf. Proc., Warrendale, 69(1986), 719.

[5] V. C. Galindo, R. D. Morales, J. A. Romero, J. F. Chavez and M. V. Toledo: Steel Res., 71(2000), 107.

[6] O. Wijk: $7^{\text {th }}$ International Conf. on Refining Process, MEFOS, Lulea, Sweden, (1995), 35.

[7] D. Bolger: Steelmak. Conf. Proc., Chicago, 77(1994), 531.

[8] N. U. Girase, S. Basu and S. K. Choudhary: Ironmak. Steelmak., 34(2007), 506.

[9] A. Kumar, G. M. Kumar, S. K. Ajmani and S. K. Singh: Ironmak. Steelmak., 44(2017), 210.

[10] R. Rastogi and A. W. Cramb: Steelmak. Conf. Proc., ISS, 84(2001), 789 .

[11] W. K. Tiekink, A. Pieters and J. Hekkema: Steelmak. Conf. Proc., Chicago, 77(1994), 423.
[12] Y. Vermeulen, B. Coletti, B. Blanpain, P. Wollants and F. Haers: Steelmak. Conf. Proc., ISS, 83(2000), 175.

[13] S. Ogibayashi, M. Uchimura, Y. Maruki, D. Mizukoshi and K. Tanizawa: Steelmak. Conf. Proc., Toronto, ISS, 75(1992), 337.

[14] Y. Fukuda, Y. Ueshima and S. Mizoguchi: ISIJ Int., 32 (1992), No. 1, 164.

[15] J. Poirier, B. Thillou, M. A. Guiban, G. Provost: Steelmak Conf. Proc., 78(1995), 451.

[16] H. Yamamura, Y. Ueshima and T. Matsumiya: SCANMET II $2^{\text {nd }}$ International Conf. on Process Development in Iron and Steelmaking, 6-9 June (2004), Lulea, Sweden, 365.

[17] R. Dekkers, B. Blanpain and P. Wollants: Metall. Mater. Trans. B, 34B (2003), 161.

[18] K. Beskow and D. Sichen: Scand. J. of Metallurgy, 32 (2003), 320.

[19] K. Beskow, N. N. Viswanathan, L. Jonsson and D. Sichen: Metall. Mater. Trans. B, 32B (2001), 319.

[20] A. W. Cramb, R. Rastogi, and R. L. Maddalena: The Making, Shaping and Treating of Steel, 11th Edition, Casting Volume: The AISE Steel Foundation, Pittsburgh, PA (2003), 269.

[21] H. Goto and K. Miyazawa: ISIJ Int., 38 (1998), No. 3, 256.

[22] C. Liu, F. Huang, J. Suo, and X. Wang: Metall. Mater. Trans. B, 47B (2016), 989.

[23] J. H. Shin, Y. Chung, and J. H. Park: Metall. Mater. Trans. B, 48B (2017), 46.

[24] L. Z. Kong, Z. Y. Deng, and M. Y. Zhu: ISIJ Int., 57 (2017), 1537.

[25] S. K. Choudhary and A Ghosh: ISIJ Int., 48(2008), No. 11, 1552.

[26] K. C. Ahlborg: 5th International Clean Steel Conf, Hungary, June 1997, 15.

[27] Y. Itoh, M. Hino and S. Ban-Ya: Metall. Mater. Trans. B, 28B (1997), 953.

[28] A. Kumar, S. K. Choudhary and S. K. Ajmani: ISIJ Int., 52 (2012), 2305.

[29] G. Yang and X. Wang: ISIJ Int., 55(2015), 126.

[30] S. Dawson: Steel Times, (1992), 127.

[31] S. Dawson: Continuous Casting, ISS, Vol. 6, (1992), 53. 